\title{
ANALISIS PENERAPAN PSAK NO. 16 TENTANG ASET TETAP PADA PT. BANK SULUTGO
}

\author{
Natalia Punusingon ${ }^{1}$, Harijanto Sabijono ${ }^{2}$, Sintje Rondonuwu ${ }^{3}$ \\ 1,2,3 Jurusan Akuntansi, Fakultas Ekonomi dan Bisnis, Universitas Sam Ratulangi, Jl. Kampus Bahu, Manado \\ 95115, Indonesia
}

Email : nataliapunusingon@gmail.com

\begin{abstract}
In an operational company requires production factors to support the company in achieving its objectives. Of the several types of assets, there is one of the most important assets in supporting the company's operations, namely fixed assets. This study aims to find out that the company has implemented a fixed asset accounting policy that is appropriate and based on the Statement of Financial Accounting Standards (PSAK) no.16 in company activities. The method in this study is descriptive analysis method. In carrying out its accounting activities, PT. SulutGo Bank has referred to PSAK No. 16. In practice, companies distinguish types and ways of obtaining fixed assets with cash purchases or by establishing themselves, in depreciating fixed asset companies using the straight-line method and the declining balance method in accordance with applicable Accounting Standards, in terminating fixed assets whose useful lives has expired or is no longer used by removing assets from the register of ownership and releasing them through sales through auction. presentation and disclosure of assets in accordance with the pattern of financial standards and some information disclosed in financial statements.
\end{abstract}

Keywords: fixed assets, SFAS no.16, financial statements, depreciating, financial accounting standard

\section{PENDAHULUAN}

Perusahan merupakan organisasi modern yang mempunyai kegiatan tertentu dalam mencapai suatu tujuan, baik itu perusahaan jasa, perusahaan dagang maupun perusahaan manufaktur. Biasanya disamping mencari laba, tujuan perusahaan yaitu mencakup pertumbuhan yang terus menerus, kelangsungan hidup, dan kesan positif di mata publik. Dalam mendukung perkembangan perusahaan dibutuhkan adanya informasi keuangan. (Martani, 2013: 15). Untuk menjalankan suatu bidang usaha, perusahaan memiliki aset yang diharapkan dapat memberikan manfaat ekonomi bagi perusahaan di masa yang akan datang. Dari beberapa jenis aktiva, ada salah satu aset yang penting dalam menunjang operasional perusahaan, yaitu aset tetap. (Martani, 2013: 25). Dalam kelancaran operasional perusahaan aset tetap memiliki peran yang sangat penting untuk perusahaan dan untuk itu diperlukan kebijakan yang tepat dalam pengelolaan aset tetap.

Di dalam PSAK No.16 akuntansi aset tetap terbagi atas enam poin yaitu Pengakuan Aset, Pengeluaran Aset Tetap, Pengukuran Aset Tetap, Penyusutan Aset Tetap, Penghentian dan Pelepasan Aset Tetap, dan Penyajian dan Pengungkapan Aset Tetap". PT. Bank SulutGo adalah perusahaan dalam bidang dana dan jasa yang banyak menggunakan aset tetap. Bagi perusahaan aset tetap ini sangat dibutuhkan dalam menjalankan kegiatan operasioanalnya. Berdasarkan uraian diatas, maka perlu untuk memahami lebih jauh mengenai kebijakan akuntansi aset tetap PSAK No. 16 Tentang Aset Tetap pada PT. Bank SulutGo. 


\section{TINJAUAN PUSTAKA}

Konsep Akuntansi. Akuntansi adalah sistem informasi dan pengukuran yang mengidentifikasi, mencatat dan mengkomunikasikan informasi yang relevan, dapat diandalkan, dan dapat dibandingkan tentang kegiatan bisnis organisasi. Wild, Shaw dan Chiappetta (2014:3). Akuntansi adalah proses pencatatan, penggolongan yang terjadi dalam perusahaan / organisasi lain serta penafsiran terhadap hasilnya. Mulyadi (2014:10).

Konsep Akuntansi Keuangan. Akuntansi keuangan adalah bagian dari akuntansi yang berkaitan dengan penyiapan laporan keuangan untuk pihak luar, seperti pemegang saham, kreditor, pemasok, serta pemerintah. Prinsip utama yang dipakai akuntansi keuangan dalam persamaan akuntansi (asset $=$ liabilitas + ekuitas). Suhayati. E dan Anggadini, S.D (2013). Akuntansi keuangan adalah menghasilkan informasi keuagan tentang sebuah entitas. Informasi keuangan yang dihasilkan adalah laporan keuangan. Laporan keuangan yang disusun berdasarkan standar merupakan laporan keuangan untuk tujuan umum dan merupakan bagian dari akuntansi keuangan. Martani (2012:8).

\section{Konsep Akuntansi Aset Tetap}

Pengertian Aset Tetap. Definisi aktiva tetap menurut IAI melalui PSAK No.16 (Revisi 2011) mengemukakan pengertian aktiva tetap sebagai berikut: aset tetap adalah aset berwujud yang: (a) dimiliki untuk digunakan dalam produksi atau penyediaan barang atau jasa untuk direntalkan bahwa kepada pihak lain, atau untuk tujuan administratif; dan (b) diharapkan untuk di gunakan selama lebih dari satu periode.

Klasifikasi Aset Tetap. Dalam PSAK No.16 Revisi (IAI, 2015:16) klasifikasi aset tetap menurut kelasnya dimana suatu kelas aset tetap adalah pengelompokan aset-aset yang memiliki sifat dan kegunaan yang serupa dalam operasi entitas. Berikut adalah contoh dari kelas tersendiri: Tanah, Tanah dan bangunan, Mesin, Kapal, Pesawat udara, Kendaraan bermotor, Perabotan, Peralatan kantor.

Pengakuan Aset Tetap. PSAK 16 menyatakan bahwa aset tetap harus diakui jika dan hanya jika (paragaraf 7).

a. Besar kemungkinan manfaat ekonomis yang berhubungan dengan aset tersebut akan mengalir ke perusahaan.

b. Biaya perolehan aset dapat diukur secara andal.

Pengeluaran Aset Tetap. Pengeluaran Aset Tetap adalah semua biaya yang keluar guna memperpanjang umur manfaat dari Aktiva Tetap seperti reparasi yang bersangkutan dengan bangunan perusahaan. Martani (2012).

Pengukuran Aset Tetap. Harga perolehan aset tetap adalah semua biaya yang dikeluarkan untuk memperoleh aset tetap sampai aset tetap tersebut berada pada perusahaan dan siap digunakan untuk kegiatan operasional perusahaan. Ramadhan (2015:18). Ada berbagai cara memperoleh aset tetap yang mempengaruhi penentuan biaya perolehannya yaitu pembelian tunai, pembayaran tangguhan, pembelian gabungan, sumbangan dari pemerintah, dibangun sendiri, pengeluaran saham biasa, pertukarann aset tetap. Sodikin (2013:147).

Penyusutan Aset Tetap. Faktor-faktor yang harus diperhatikan dalam menghitung beban penyusutan adalah Biaya Perolehan, Umur Manfaat, Nilai Sisa/Residu, Jumlah Biaya yang dapat disusutkan/Jumlah Tersusutkan, Jumlah Tercatat/Nilai Buku. Pontoh (2013:358). Pengelompokan berdasarkan penyusutan mengenal dua macam jenis aset tetap, yaitu: Depreciated Plant Asets,Undepreciated Plant Asets. Kirana (2013:2). Ikatan Akuntansi Indonesia mengungkapkan bahwa metode-metode penyusutan dapat dilakukan dengan berbagai metode yang dapat dikelompokkan menurut kriteria berikut:

1. Metode Garis Lurus (Straight Line Method). Metode ini adalah metode depresiasi yang paling sederhana dan banyak digunakan. Dalam metode ini, beban depresiasi tiap periode jumlahnya sama. 
2. Metode Saldo Menurun (Diminishing Balance Method). Metode jumlah menurun ini akan menghasilkan beban penyusutan yang menurun setiap periode.

3. Metode Jumlah Unit (Sum Of The Unit Method). Dalam metode ini umur kegunaan masa manfaat aktiva tetap ditaksir dalam satuan jumlah unit hasil produksi.

Pencatatan penyusutan dapat menggunakan dua metode yaitu Metode Langsung (Direct Methods), Metode Akumulasi (Accumulated Methods).Suhayati. E dan Anggadini, S.D (2013:251).

Penghentian dan Pelepasan Aset Tetap. PSAK 16 menyatakan "aset tetap dihentikan pengakuannya (paragraf 67): (a) pada saat dilepaskan; atau (b) pada saat tidak ada manfaat ekonomis masa depan yang diharapkan dari penggunaan atau pelepasannya.

Penyajian dan Pengungkapan Aset Tetap. Aset tetap disajikan dalam sebesar nilai buku yaitu harga perolehan dikurangi akumulasi penyusutan dan akumulasi kerugian penurunan nilai. Pengungkapan aset tetap dalam laporan keuangan merupakan penjelasan dari pos-pos aset tetap dalam laporan keuangan. Martani (2012).

Laporan Keuangan. Laporan keuangan merupakan bentuk pertanggungjawaban atas kegiatan operasional suatu badan usaha, dalam hal ini kegiatan yang berhubungan dengan keuangan kepada pemilik usaha atau kepada pihak-pihak yang berkepentingan. Martani (2012). Dalam upaya untuk membuat keputusan yang rasional, pihak ekstern perusahaan maupun pihak intern perusahaan seharusnya menggunakan suatu alat yang mampu menganalisis laporan keuangan yang disajikan oleh perusahaan yang bersangkutan. Suhayati. E dan Anggadini, S.D (2013).

Penelitian Terdahulu. Agnes Fanda Salainti (2013). Evaluasi Penerapan Akuntansi Aset Tetap pada PT. PLN (PERSERO) Wilayah Suluttenggo Area Manado. Hasil Penelitian menjelaskan bahwa perlakuan akuntansi atas aset tetap yang diterapkan perusahaan sudah sesuai dengan PSAK No. 16. Perusahaan melakukan penyusutan terhadap seluruh jenis aset tetapnya kecuali tanah dan aset tetap dalam pelaksanaan menggunakan metode penyusutan yang seragam untuk setiap jenis aset tetap yaitu menerapkan metode garis lurus. Veronika Debora Koapaha (2014). Evaluasi Penerapan Perlakuan Akuntansi Aktiva Tetap pada RSUP Prof. Dr. R. D. Kandou Manado. Hasil penelitian menjelaskan RSUP Prof. Dr. R. D. Kandou Manado telah menjalankan kegiatamn akuntansinya berpedoman pada kebijakan akuntansi persuhaan pada PSAK No. 16.

\section{METODE PENELITIAN}

Jenis Penelitian. Dalam penelitian ini penulis menggunakan jenis penelitian yang bersifat deskriptif kualitatif. Penelitian ini digunakan untuk menyelidiki keadaaan, kondisi atau beberapa hal yang terjadi di PT. Bank SulutGo tentang penerapan aset tetap secara lugas dan hasilnya dapat dipaparkan dalam bentuk laporan penelitian.

Tempat dan Waktu Penelitian. Penelitian ini dilakukan pada PT. Bank SulutGo yang bertempat di Jalan Sam Ratulangi No.9, Manado, Sulawesi Utara. Waktu penelitian dimulai pada bulan Maret sampai dengan bulan Mei 2018.

Prosedur Penelitian. Prosedur langkah-langkah penelitian yang dilakukan oleh penulis adalah mengidentifikasi masalah, merumuskan masalah, melakukan kunjungan objek penelitian, mengumpulkan data, menganalisis data dan membuat kesimpulan.

Jenis Data dan Sumber Data. Dalam penelitian ini, jenis data yang digunakan adalah data kualitatif yaitu sejarah PT Bank SulutGo dan data kuantitatif yaitu laporan keuangan PT. Bank Sulut Go periode 2016-2018. sumber data yang dipakai adalah sumber primer dan sekunder. Data primer yang dipakai adalah data yang diambil langsung pada PT. Bank SulutGo. Sedangkan data sekunder yang dipakai dalam penelitian adalah data dari lembaga pengumpul data dan kepustakaan. 
Teknik Pengumpulan Data. Dalam penelitian ini penulis menggunakan Teknik pengumpulan data yaitu; Wawancara, Dokumentasi, dan Media Elektronik.

Metode Analisis. Berdasarkan sumbernya, metode analisis data yang digunakan dalam penelitian ini adalah metode analisis deskriptif kualitatif. yaitu data dan informasi dikumpulkan dengan maksud peneliti mengevalusi bagaimana penerapan akuntansi atas aset tetap yang dilakukan oleh PT. Bank SulutGo dengan Pernyataan Standar Akuntansi Nomor 16 yang berlaku apa sudah sesuai atau tidak.

\section{HASIL PENELITIAN DAN PEMBAHASAN}

\subsection{Hasil Penelitian}

Sejarah dan Pertumbuhan Bank SulutGo. Pada tahun 1961 PT. Bank Sulut di kenal dengan PT. Bank Pembangunan Daerah Sulawesi Utara. Selang tahun 1962- 1964 terjadi perubahan-perubahan tentang ketentuan-ketentuan pokok Bank Pembangunan Daerah, Bank Sulut menandatangani Perjanjian Rekapitalisasi. Pada tahun 1999 Bank Pembangunan Daerah Sulawesi Utara dari Perusahaan Daerah menjadi Perseroan Terbatas Bank Pembanguan Daerah Sulawesi Utara. Selanjutnya Bank Sulut lepas dari program rekapitalisasi dan terus meningkatkan eksistensinya dengan membuka beberapa jaringan kantor.Pembukaan Cabang Pertama di luar daerah Sulawesi Utara dan Gorontalo yakni di daerah khusus Ibukota Jakarta pada tanggal 19 Januari 2004 yang bertempat di Gedung Jaya, Jl. M. H. Thamrin, Jakarta.

Pengakuan Aset Tetap. Berdasarkan Observasi dan Wawancara, PT. Bank SulutGo memiliki aset tetap yang terdiri dari Bangunan, Perabot, Kendaraan Bermotor, Inventaris kantor, Hardware. PT. Bank SulutGo memiliki dua cara dalam memperoleh aset tetap, yaitu:

1. Pembelian secara tunai. Cara perolehan ini menyangkut inventaris bergerak. Pada PT. Bank SulutGo sebelum membeli suatu aset tetap, terlebih dahulu dibuat perencanan pembelian aset tetap.

2. Dibangun sendiri. Bila aset tetap diperoleh dengan cara membangun sendiri, maka biaya untuk membangun aset tersebut ialah biaya untuk izin bangunan, biaya untuk arsitek, biaya untuk bahan mentah, buruh/pekerja langsung, dan pembayaran untuk para kontraktor.

Pengeluaran Setelah Perolehan Aset Tetap. Berdasarkan Observasi dan pengelolahan data PT. Bank SulutGo, pengeluaran setelah peroleh aset tetap yang dilakukan oleh PT. Bank SulutGo guna dalam memperpanjang masa dan manfaat dari kinerja aset tetap.

Pengukuran Aset Tetap. Berdasarkan observasi pada PT. Bank SulutGo, pengukuran aset tetap yang dilakukan oleh PT. Bank SulutGO guna untuk kegiatan operasional perusahaan adalah sebesar Rp.160.993.272.059. Total biaya yang dikeluarkan PT. Bank SulutGo dalam memperoleh aset tetap guna operasional perusahaan terdiri dari Kendaraan motor, kendaraan mobil, inventatis mesin kantor, inventaris perabot, hardware dan juga bangunan.

Penyusutan Aset Tetap. Berdasarkan observasi dan pengelolahan data dari PT. Bank SulutGo menggunakan dua metode penyusutan yaitu metode garis lurus, diterapkan dalam menghitung penyusutan bangunan dan Metode saldo menurun, digunakan dalam menghitung penyusutan invetaris bergerak beruoa kendaraan.

Penghentian dan Pelepasan Aset Tetap. Berdasarkan Observasi, aset tetap pada PT. Bank SulutGo dapat dihentikan pengakuannya, apabila aset tersebut rusak diakibatkan bencana, kebakaran, dicuri ataupun habis masa manfaatnya/ tidak dapat disusutkan lagi. Aset tetap yang telah habis masa manfaatnya, tetapi masih dapat digunakan dalam kegiatan operasional perusahaan, nilai bukunya ditetapkan sebesar Rp. 1,00 dan sudah tidak dapat disusutkan lagi. Salah satu perlakuan penghentian dan pelepasan aset tetap pada PT. Bank SulutGo yaitu dijual. Pelepasan aset tetap pada PT. Bank SulutGo yang dijual dilakukan 
dengan cara lelang baik kepada pihak intern (pegawai perusahaan) maupun kepada masyarakat umum, dengan pertimbagan untuk memperoleh harga yang menguntungkan PT. Bank SulutGo. Contohnya, Rumah dinas dan kendaraan bermotor. Pembayarannya bisa secara tunai maupun kredit khususnya bagi pegawai.

Penyajian dan Pengungkapan Aset Tetap. Laporan keuangan memiliki tujuan untuk memberi informasi yang tepat dan transparan kepada pengguna laporan, sehingga untuk menyajikan aset tetap harus menggambarkan keadaan aset tetap dan dapat dipahami oleh pengguna laporan keuangan sehingga pengambilan keputusan bisa dilakukan secara tepat. PT. Bank SulutGo Manado menggolongkan aktiva tetapnya berdasarkan presentase penyusutannya yang diatur dalam aturan perpajakan, yaitu golongan I, II dan III.

\subsection{Pembahasan}

Pengakuan. Dari tabel perbandingan pengakuan aset tetap oleh PT. Bank SulutGo Manado dengan PSAK No.16 berdasarkan hasil penelitian, dengan memberikan manfaat ekonomi, aset tetap yang diperkirakan akan memberikan manfaat dan menunjang operasional perusahaan sehingga perusahaan bisa menjalankan kegiatan operasional perusahaan dalam melayani konsumen. Dalam hal ini pengakuan aset perusahaan telah sudah sesuai dengan panduan yang dimiliki oleh perusahaan dan tidak menyimpang dari PSAK No. 16.

Pengeluaran Setelah Perolehan Aset Tetap. Dari tabel perbandingan dapat dilihat PT. Bank SulutGo melakukan pengeluaran untuk pemeliharaan dan perbaikan aset tetap dengan memperpanjang waktu manfaatnya diwaktu yang akan datang dengan meningkatkan kapasitas dan standar kerja ataupun mutu produksi. Pengeluaran-pengeluaran ini pada prinsipnya harus dikapitalisasikan pada jumlah tercatat pada aset yang bersangkutan. Namun pengeluaran yang dapat dikapitalisasikan hanya pengeluaran modal yang dimaksudkan untuk menambah nilai dari aset tetap. Sedangkan untuk pengeluaran yang tidak menambah masa manfaat diakui dalam rugi laba saat terjadinya sebagai beban. Prinsip alokasi biaya untuk pengeluaran ini tidak dibahas spesifik didalam Standar Akuntansi Keuangan, namun untuk menghindari kesalahan pada saat perhitungan laba untuk serangkaian periode akuntansi, maka ada baiknya pengeluaran-pengeluaran untuk aset tetap ditetapkan dan dikelompokkan. Dalam kebijakan akuntansi perusahaan, dinyatakan bahwa pengeluaran untuk menambah masa manfaat dan umur ekonomis aset tetap digolongkan kedalam pengeluaran modal, dan dikapitalisasikan dengan mendebet perkiraan yang bersangkutan.

Pengukuran Aset Tetap. Berdasarkan penelitian dapat diuraikan mengenai perlakuan akuntansi aset tetap pada PT. Bank SulutGo, pada kebijakan perusahaan tercantum bahwa anggaran perolehan aset tetap terdiri dari harga beli aset tetap serta anggaran yang dikeluarkan sampai aset yang tersebut siap digunakan. Selanjutnya untuk aset tetap yang diperoleh melalui transaksi moneter, pencatatannya berdasarkan atas nilai wajar dari asest yang diperoleh atau diserahkan, mana yang lebih layak berdasarkan data/bukti yang tersedia. Pencatatan untuk transaksi tidak dijelaskan dengan rinci oleh perusahaan, tapi perlakuan aset tetap yang dicantumkan dalam kebijakan perusahaan telah sesusai dengan standar akuntansi yang berlaku. Untuk aset yang dibangun sendiri, dicatat berdasarkan seluruh anggaran yang terjadi dengan pembangunan aset tetap tersebut hingga aset tetap siap untuk digunakan. Dalam membangun aset tetap, perusahaan melakukan kerja sama dengan pihak kontraktor, dan melakukan perencanaan pembiayaan sebelum aset dibangun. Dari segi kebijakan hal ini tidak menyimpang dari PSAK No. 16 , namun secara praktiknya, perusahaan tidak memperinci mengenai perencanaan pembiayaan serta mendeskripsikan bagaimana cara pencatatan biaya perencanaan dan biaya dengan pihak kontraktor. Perusahaan menerapkan kebijakan revaluasi yaitu penilaian kembali terhadap aset tetap yang dimiliki apabila sudah diperoleh dasar yang otoritatif. Menurut Standar Akuntansi Keuangan, jika perusahaan memilih model revaluasi, maka pada saat aset diakui, aset tetap yang dicatat pada jumlah revaluasinya. Perusahaan sudah menerapkan Standar Akuntansi Keuangan jika dilihat dari 
Pedoman Kebijakan Perusahaan yang dimiliki, namun dalam pencatatannya perusahaan tidak mendeskripsikan apa perusahaan sudah pernah melakukakn revaluasi dan bagaimana perusahaan mencatat aset pada nilai revaluasiannya.

Penyusutan Aset Tetap. Berdasarkan tabel perbandingan dapat dilihat penyusutan menurut PT. Bank SulutGo telah sesuai dengan penerapan PSAK No. 16 dimana aset tetap yang telah disusut secara terpisah. Penyusutan aset tetap pada PT. Bank SulutGo dilakukan dengan metode garis lurus dan metode saldo menurun. Aset tetap gedung, kendaraan, inventaris kantor mengalami perlakuan penyusutan yang sama. Biaya penyusutan aset tetap dimasukkan dalam daftar rugi laba sebagai unsur biaya dan akumulasi penyusutan dimasukkan dalam neraca disisi debet yang mengurangi jumlah keseluruhan aset tetap. Dari hasil perbandingan ini terlihat kebijakan perusahaan telah menerapkan perlakuan penyusutan yang ada pada PSAK No. 16.

Penghentian dan Pelepasan Aset Tetap. Dari tabel perbandingan dapat dilihat bahwa aset tetap milik PT. Bank SulutGo yang sudah tidak digunakan lagi dalam operasi dihapus dari data aset tetap dan dibukukan pada perkiraan aset tetap dan pencatatannya berdasarkan nilai wajar aset tersebut. Pemahaman dari perusahaan tidak menyimpang dari Standar Akuntansi Keuangan. PT. Bank SulutGo mengakui ada keuntungan atau kerugian dalam laporan laba rugi berkaitan dengan pelepasan aset tetap yang bersangkutan. Maksudnya adalah ketika perusahaan melepas aset tetap maka keuntungan atau kerugian yang timbul harus diakui oleh perusahaan. Contohnya, jika aset tetap dilepas dengan cara dijual maka keuntungan dari penjualan aset tetap harus diakui perusahaan. Menurut PSAK No 16, pelepasan aset tetap dapat dilakukan dengan cara menjual aset, disewakan atau disumbangkan. Hal ini sudah diterapkan pada PT. Bank SulutGo, aset yang sudah tidak lagi dipakai oleh PT. Bank SulutGo bisa dilepas dengan cara dijual/ lelang. Cara mencatat aset tetap yang dilepas dengan cara dijual yaitu mendebit pendapatan dari pelepasan dan mengkredit akun aset tetap yang bersangkutan.

Penyajian dan Pengungkapan Aset Tetap. Berdasarkan hasil penelitian yang dilakukan pada PT. Bank SulutGo, terlihat perusahaan menyajikan aset tetap sama dengan nilai bukunya, yaitu harga perolehan aset dikurangi akumulasi penyusutan. Hal tersebut sesuai dengan PSAK No. 16. Pada perusahaan, jenis aset tetap seperti tanah, inventaris kantor, bangunan dan lainnya harus dinyatakan dalam neraca dengan terpisah atau diperinci dalam catatan atas laporan keuangan berdasarkan masa manfaatnya. PT. Bank SulutGo telah menerapkan kebijakan ini dan kebijakan ini tidak menyimpang dari Standar Akuntansi Keuangan. Pengungkapan aset tetap pada perusahaan dituangkan secara langsung dalam neraca (face) dan berupa Catatan atas laporan keuangan. Pada PSAK No. 16 diharuskan untuk mengungkapkan dasar penilaian agar jumlah tercatat bruto dapat ditentukan. PT. Bank SulutGo tidak mengungkapkan mengenai dasar penilaian yang dipakai, sehingga hal ini menyimpang dari standar akuntansi keuangan. Pada beberapa poin juga terlihat bahwa kebijakan perusahaan tidak menjelaskan mengenai pengungkapan umur manfaat atau tarif penyusutan yang digunakan dan beberapa hal lainnya dan ini tidak sesuai dengan PSAK No. 16 yang mengharuskan perusahaan untuk mengungkapkannya.

\section{KESIMPULAN DAN SARAN}

\subsection{Kesimpulan}

1. Secara umum dalam kegiatan akuntansi khususnya dalam pengelolaan aset tetap PT. Bank SulutGo prinsipnya sudah mendekati Pernyataan Standar Akuntansi Keuangan (PSAK) No. 16, baik dalam hal penilaian/pengukuran, pengeluaran aset, penyusutan aset tetap, penghentian dan pelepasan aset tetap bahkan penyajian dan pengungkapan aset tetap sudah sesuai dengan PSAK No. 16. 
2. Kurang informatif dalam mengidentifikasi aset tetap dalam daftar aset tetap. Aset digabung dalam satu daftar meskipun diperoleh ditahun yang berberda.untuk masa manfaat dan pemakaian dicantumkan.

\subsection{Saran}

1. Penulis menyarankan kepada perusahaan untuk lebih memperhatikan revaluasi aset secara teratur, guna memastikan jumlah tercatat tidak berbeda dengan jumlah yang ditentukan pada akhir periode pelaporan dengan nilai wajarnya.

2. Secara umum pengungkapan yang tercantum pada kebijakan entitas dan perlakuan entitas dalam penerapannya sudah baik. Namun, agar laporan keuangan serta catatan atas laporan keuangan lebih informatif sehingga dapat dimengerti oleh pemakai Laporan Keuangan.

\section{DAFTAR PUSTAKA}

Ikatan Akuntan Indonesia (2011) Pernyataan Standar Akuntasi Keuangan No.16 Aset Tetap. Jakarta.

Ikatan Akuntan Indonesia (2015) Pernyataan Standar Akuntasi Keuangan No.16 Aset Tetap. Jakarta.

Martani, D (2012) Akuntansi Keuangan Menengah Berbasis PSAK. Edisi 1. Salemba Empat: Bandung.

(2013) Akuntansi Keuangan Menengah Berbasis PSAK. Edisi 4. Salemba Empat: Bandung.

Mulyadi. M (2014). Pengantar Akuntansi. Edisi ke 4. Yogyakarta: BPE Universitas Gajah Mada.

Pontoh, W. (2013) Akuntansi Konsep dan Praktik. Penerbitan Halaman Moeka:Jakarta Barat. Profil Sejarah dan Perkembangan PT. Bank SulutGO

Ramadhan, A. (2015) Analisis Penilaian Akuntansi Atas Aset Tetap Berwujud Berdasarkan Etap (Entitas Tanpa Akuntibilitas Publik) Pada PT. Sumber Pratama Raya Palembang. Skripsi Fakultas Ekonomi Universitas IBA. Palembang. http://portalgaruda.id.

Sodikin, S. S. (2013) Akuntansi Pengantar 2 Berbasis SAK ETAP 2009. Edisi Keenam. Penerbit UPP STIM YKPN: Jogjakarta.

Suhayati, E., dan Anggadini, S. D. (2013) Akuntansi Keuangan. Edisi Pertama. Penerbit Graha Ilmu: Yogyakarta.

Veronika D. K. (2014) "Evaluasi Penerapan Perlakuan Akuntansi Aktiva Tetap Berdasarkan PSAK No.16 Pada RSUP Prof. Dr. R. D. Kandou Manado". Jurnal EMBA. ISSN 2303-1174. Vol. 2. http://ejournal.unsrat.ac.id.

Wild, J. J., Ken, W. S., dan Barbara, C. (2014) Financial Accounting Information For Decisions is A Asian Adaption Of Fundamental Accounting $20^{\text {th }}$ Edition. Mc Gra Hill Aducation (Asia): Singapore. 